\title{
REVIEW PAPER ON ANALYSING THE INFORMATION SECURITY IN INTERNET BANKING
}

\author{
Mukta Sharma', R.B. Garg ${ }^{2}$ \\ ${ }^{1}$ Research Scholar, TMU, Moradabad \\ ${ }^{2}$ Professor, Technia, Delhi, India
}

\begin{abstract}
Innovation is doing new things, which leads to change. With the growth in information technology, the world has revolutionized. It has actually changed the way of communication, of doing business, of transacting and even of thinking. The impact of information technology especially internet is visible everywhere in almost all domains like hospitality, education, banking, etc. Banking sector has diversely grown. It has been offering various services to the customers. In this paper we will see how much banks and the customers are comfortable using the Internet banking, what kind of services are being offered by various banks, why people were and are rigid, hesitant and reluctant to accept e-banking, what factors and initiative banks should take to bring customers towards e-banking.
\end{abstract}

This paper presents a systematic review of more than 60 research papers which will start from the basic benefits for adopting internet banking, to the issues involved in the same specifically related to the security. To make a decision on the usage of internet banking the most imperative aspect is security. There are various security threats and there are multiple researches going on for providing a better security measure.

Rational of the review-Discrete geographical locations are considered to comprehend the consumers' behaviour for adopting ebanking. To scrutinize factors which affect customer adoption of online banking system and how this issue can be resolved? The objectives of my study are as follow:

- $\quad$ Explore the Online Banking Sector and the Security Issues faced by them.

- Analyze the Impact of Security on the End Users.

- $\quad$ Anticipate the Security threats, which can hamper the information.

Review methodology- Literature has been taken from IEEE, ScienceDirect, Emerald Fulltext, Springer, ACM, and various other journals. The search engines Google Scholar and Scopus were also used to ensure coverage of publications in other databases. Conference papers, masters theses, textbooks have also been incorporated. The following criteria were used to search these sources and select the papers:

- $\quad$ The keywords Internet banking, adoption, security, security threats, security measures, online transaction and acceptance were used to search the titles and abstracts of the papers

- $\quad$ Only openly accessible studies were taken due to permission restrictions from the publishers.

To comprehend the role of internet in banking sector a conceptual approach is used 66 articles were selected for classification. It has been categorized into 3 categories Adoption (26), Security threats (16) and security solutions (24).

Findings- To enhance adoption rates a framework is proposed to establish a strategy. It also analyzes the customer's viewpoint towards security. To observe various reasons for actually opting for internet banking

Research limitations/implications- Research design is exploratory in nature hence; the results of the study are not very conclusive.

Keywords-Internet banking, e-frauds, adoption, acceptance, security, security threats, security measures and online transaction

Paper Type- Conceptual Paper $* * *$ 


\section{INTRODUCTION}

The way the organizations do the business, manage the tasks \& cater the customers has got revolutionized with the technology enhancements. The banking sector occupies a pivotal position in the global economy [17]. Now, we are witnessing rapid development in banking industries to enable electronic payment through Internet as an example [27]. Online banking appeals very well to the young, the more educated and affluent segments as well. The banks have the following advantages: saving the cost, acquire new customer, geographically reach-out, Improved Image, Consumer acceptance of internet banking, convenience, enable mass customization, Marketing and communication, Enable innovation, Development of non-core business [17]. Ebanking means providing the banking services electronically instead of the banks' branches. New channels in delivering banking services such as ATM, telephone banking have made banking services more convenient. The newest mode for retail banking is online. Online banking connects the bank \& its customers over the internet. Thus bringing all the services offered by the banks at the customers' locations, may it the home computer, the office workstation of the mobile phone or tablet phone. Without going to the bank, then user can use most of the retail banking services- such as balance reporting $\&$ transactions of funds.

To study information security in e-banking, this paper is classified into 3 sections.

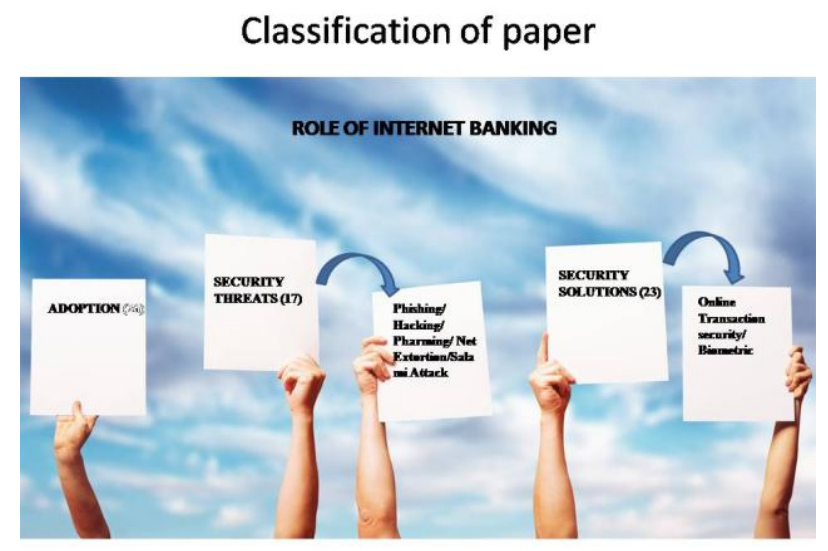

Fig. 1 Classification of paper

\section{Year Wise Bifurcation of the papers}

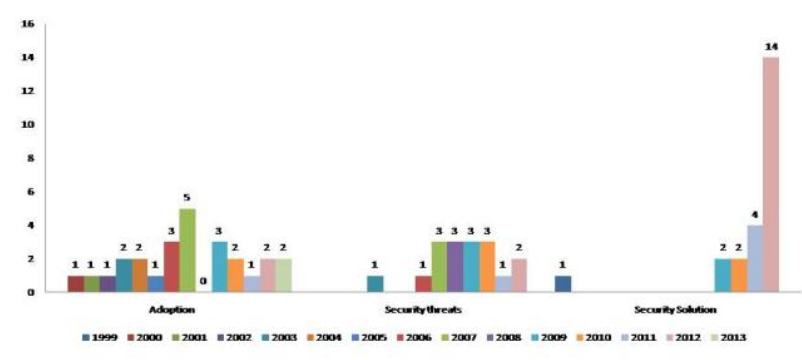

Fig. 2 Year Wise Bifurcation of the papers

\section{ADOPTION}

Papers on adoption behaviour of the customers from varied geographical location has been reviewed. The objective behind including this set of paper was to read and identify the areas where different countries are giving more importance, how much they have excel, what services they are offering to their customers online, how is the customer behaviour, banks and customers are facing some issues in accepting the new concept of ebanking. We have reviewed many papers in context to the adoption behaviour and issues in accepting the online banking in various countries like Europe, Iraq, China, UK, Malaysia, Australia, US etc.

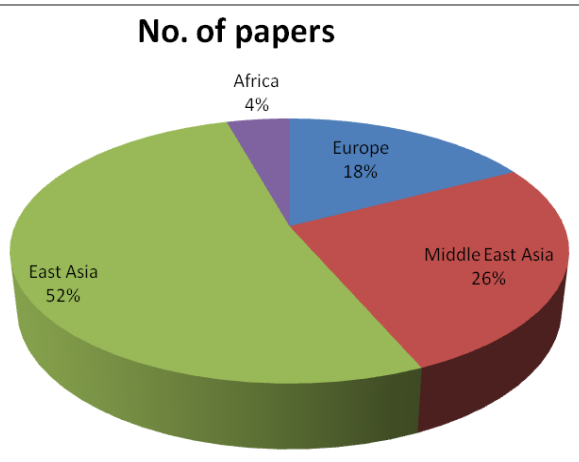

Fig. 3 Region wise distribution of Adoption papers

\begin{tabular}{|l|l|l|}
\hline$\#$ & Objective \& Findings & $\begin{array}{l}\text { Refere } \\
\text { nce }\end{array}$ \\
\hline 1 & $\begin{array}{l}\text { 12 UK net banking systems were chosen. } \\
\text { They were analysed on various aspects } \\
\text { like speed, content, design, navigation } \\
\text { interactivity, and security features to } \\
\text { satisfy the need of the customer. User } \\
\text { satisfaction depends on Web site features. }\end{array}$ & 17 \\
\hline 2 & $\begin{array}{l}8 \text { banks of Kuwait were studied. The } \\
\text { review was done with the perspective of } \\
\text { senior IT managers \& potential customers } \\
\text { to find the online banking issues. Around } \\
\text { 50 percent of the banks have systems } \\
\text { under development \& rest offer } \\
\text { operational online banking services. }\end{array}$ & 7 \\
\hline
\end{tabular}




\begin{tabular}{|c|c|c|}
\hline & $\begin{array}{l}\text { Internet security has been observed to be } \\
\text { a big challenge to online banking. }\end{array}$ & \\
\hline 3 & $\begin{array}{l}\text { In a survey, } 845 \text { cases were taken across } \\
\text { the Internet to understand behaviour of } \\
\text { users' for e-banking. In this study, author } \\
\text { has mentioned trust on the bank is also an } \\
\text { impact factor. The analysis is done using } \\
\text { structural equation modelling. }\end{array}$ & 15 \\
\hline 4 & $\begin{array}{l}\text { The study was an attempt to understand } \\
\text { the difference in behaviour of people who } \\
\text { were using internet banking they were } \\
\text { called adopters and the others were called } \\
\text { non adopters. The results suggest that } \\
\text { customers were positive about the usage } \\
\text { of internet banking whether they were } \\
\text { adopters or non adopters. However } \\
\text { adopters were more innovative as } \\
\text { compared to non adopters also adopters } \\
\text { found service to be more convenient and } \\
\text { less complex. }\end{array}$ & 41 \\
\hline 5 & $\begin{array}{l}\text { To improve Internet-based e-banking } \\
\text { systems in Taiwan a research was } \\
\text { conducted on a sample of } 123 \text { users. A } \\
\text { theoretical framework, the extended } \\
\text { technology acceptance model is used. It } \\
\text { gave a critical individual difference } \\
\text { variable, computer self-efficacy, It shown } \\
\text { to have significant impact on the } \\
\text { willingness to use the e-banking. } \\
\text { Perceived credibility about security and } \\
\text { privacy affects intention by users to adopt } \\
\text { the Internet-based transaction systems. }\end{array}$ & 58 \\
\hline 6 & $\begin{array}{l}\text { Based on a random sample of, a } \\
\text { descriptive study was conducted to } \\
\text { understand adoption of Internet banking } \\
\text { among sophisticated consumers. } \\
\text { Professionals, geo-locations, attitude, \& } \\
\text { behaviour of e-banking users and non- } \\
\text { users were examined. }\end{array}$ & 50 \\
\hline 7 & $\begin{array}{l}\text { The study was done on Hong Kong bank } \\
\text { customers'. It aimed to focus on } \\
\text { psychological beliefs about the positive } \\
\text { attributes possessed by four major } \\
\text { banking channels, i.e. branch banking, } \\
\text { ATM, telephone banking, and internet } \\
\text { banking. }\end{array}$ & 64 \\
\hline 8 & $\begin{array}{l}\text { The paper is based on Thailand } \\
\text { consumers, to identify encouraging } \\
\text { factors for e-banking. The study on } 600 \\
\text { people revealed "Features of the web site" } \\
\text { and "Perceived usefulness", to be highly } \\
\text { motivating factors. The significant } \\
\text { moderating factors are gender, } \\
\text { educational level, income, internet } \\
\text { experience and internet banking } \\
\text { experience, but not age. }\end{array}$ & 12 \\
\hline 9 & $\begin{array}{l}\text { A survey was conducted on } 127 \\
\text { customers to increase the adoption rates } \\
\text { for e-banking in Singapore. Eight factors } \\
\text { were identified which explained why }\end{array}$ & 42 \\
\hline
\end{tabular}

\begin{tabular}{|c|c|c|}
\hline & $\begin{array}{l}\text { customers are rigid in using internet } \\
\text { banking. The main factors as per the } \\
\text { priorities are: perceptions about risk; the } \\
\text { need; lacking knowledge; inertia; } \\
\text { inaccessibility; human touch; pricing and } \\
\text { IT fatigue. }\end{array}$ & \\
\hline 10 & $\begin{array}{l}\text { As per the research done on Malaysian } \\
\text { banks importance to banking needs, } \\
\text { compatibility, complexity, and trial ability } \\
\text { these four factors strongly influences the } \\
\text { adoption behaviour. Whereas, risk have a } \\
\text { negative impact on the adoption pattern. } \\
\text { Research also highlighted the customer } \\
\text { attitude and the usability, user friendliness } \\
\text { and features of banking site makes it more } \\
\text { acceptable. }\end{array}$ & 38 \\
\hline 11 & $\begin{array}{l}\text { The study is primarily focusing on the } \\
\text { benefits and challenges faced by banks to } \\
\text { adopt the products and services and on the } \\
\text { perception of customers towards services } \\
\text { offered by the banks. }\end{array}$ & 57 \\
\hline 12 & $\begin{array}{l}\text { This paper highlights the factors affecting } \\
\text { the adoption of internet banking by a } \\
\text { sparsely populated small island. }\end{array}$ & 25 \\
\hline 13 & $\begin{array}{l}\text { The study was carried on } 88 \text { banks from } \\
1997-2005 \text {, highlights the adoption } \\
\text { behaviour and factors affecting Indian } \\
\text { banks to use Internet. Specially the } \\
\text { relationship between the bank's adoption } \\
\text { decision and various bank and market } \\
\text { characteristics. To study the relationship } \\
\text { Logistic regression technique is used. }\end{array}$ & 45 \\
\hline 14 & $\begin{array}{l}\text { Based on previous research a model has } \\
\text { been proposed based on Theory of } \\
\text { Planned Behaviour (TPB). The study was } \\
\text { performed with the intention to find the } \\
\text { acceptance of electronic banking in well- } \\
\text { developed financial city. }\end{array}$ & 33 \\
\hline 15 & $\begin{array}{l}\text { The author has compared a developed } \\
\text { country, the UK, and a developing } \\
\text { country, Turkey regarding their internet } \\
\text { banking services. }\end{array}$ & 20 \\
\hline 16 & $\begin{array}{l}\text { The study was conceded from three } \\
\text { angles: (i) the current adoption rate of } \\
\text { Internet Banking; (ii) the influences of } \\
\text { perceived usefulness, perceived ease of } \\
\text { use, perceived risk and personal } \\
\text { innovativeness in information technology } \\
\text { and (iii) the potential impacts on the } \\
\text { strategic activity of banking organizations } \\
\text { operating in the Hong Kong market. }\end{array}$ & 22 \\
\hline 17 & $\begin{array}{l}\text { Customer experience a different ,kind of } \\
\text { resistances of e-banking. This paper drafts } \\
\text { information regarding this domain. A } \\
\text { typology of consumer resistance to } \\
\text { innovations is proposed and four } \\
\text { resistance segments, namely Non- } \\
\text { Resistors, Functional Resistors, } \\
\text { Psychological Resistors and Dual } \\
\text { Resistors are identified. }\end{array}$ & 59 \\
\hline
\end{tabular}




\begin{tabular}{|l|l|l|}
\hline 18 & $\begin{array}{l}\text { This paper is based in Iran and finds } \\
\text { barriers/drivers of e-banking }\end{array}$ & 1 \\
\hline 19 & $\begin{array}{l}\text { To deal with information security policy a } \\
\text { support Analytic Hierarchy Process } \\
\text { (AHP) for decision makers has been } \\
\text { proposed here. }\end{array}$ & 27 \\
\hline 20 & $\begin{array}{l}\text { A developing country China is chosen, } \\
\text { the Chinese domestic banks which are } \\
\text { actively engaged in e-banking. Based on } \\
\text { technology-organizational-environmental } \\
\text { framework a research framework is } \\
\text { developed. }\end{array}$ & 53 \\
\hline 21 & $\begin{array}{l}\text { The instances of e-fraud and its impact } \\
\text { are of Jamaica and the United Kingdom. } \\
\text { The legislator's response to the pertaining } \\
\text { crime. The increasing problem in light of } \\
\text { the global credit crisis or 'credit crunch' } \\
\text { since 2007 is also depicted in the paper. }\end{array}$ & 16 \\
\hline 22 & $\begin{array}{l}\text { The e-commerce products face lot of } \\
\text { challenges despite of many benefits. The } \\
\text { paper has shown services banking by } \\
\text { commercial banks in Kenya. }\end{array}$ & 47 \\
\hline 23 & $\begin{array}{l}\text { This paper focuses on Tunisian bank } \\
\text { customers to find the factors affecting } \\
\text { adoption. A base model, technology } \\
\text { acceptance model (TAM) and theory of } \\
\text { planned behaviour (TPB) is used, which } \\
\text { employs privacy, security, support of } \\
\text { government and technology. Structural } \\
\text { equation modeling is employed to } \\
\text { examine the inter-correlations among the } \\
\text { proposed constructs. }\end{array}$ & \\
\hline 24 & $\begin{array}{l}\text { The study is conducted in Iran. Tthe paper } \\
\text { indicated the security, web site look and } \\
\text { feel, and response time constitutes the } \\
\text { eSq-e-Service Quality scale for e- } \\
\text { banking. The scale is termed as E- } \\
\text { SERVQUAL. }\end{array}$ & 13 \\
\hline 25 & $\begin{array}{l}\text { Relationships have been depicted between } \\
\text { performance and effort expectancy, } \\
\text { influence of society, risk as a strong } \\
\text { predictor of intention. Behaviour of } \\
\text { usage can be identified by the real } \\
\text { intention to use. }\end{array}$ & 18 \\
\hline 26 & $\begin{array}{l}\text { A four dimensional model is defined on } \\
\text { the following parameters (1) openness } \\
\text { toward advanced technology as an } \\
\text { individual personality dimension, (2) } \\
\text { website usability, 3) Security and (4) } \\
\text { Green concern. }\end{array}$ & 26 \\
\hline
\end{tabular}

The overall observation on the adoption behaviour of the banks as well as the users has been established reading through the discrete papers. The managers of the associated organizations, that is the banks need to ensure that the systems installed are technically sound on the security factor. The risk of falling prey to the online hackers and face any security breach is a highest concern amongst the end users.

\section{SECURITY THREATS}

Security Threats were one of the compulsory choices to be read as the final outcome of adoption of information security has shown the rigidness in opting for online banking because of the security threats. Therefore, it was essential to go through the paper which could tell the various threats to banks and customers. We have sub classified the security threat into Phishing and hacking.

\begin{tabular}{|c|c|c|}
\hline$\#$ & Objective \& Findings & Reference \\
\hline 27 & $\begin{array}{l}\text { A framework to identify security } \\
\text { requirements so that online } \\
\text { transactions are secured. Employed } \\
\text { a qualitative approach, talked about } \\
\text { security issues from customers \& } \\
\text { banks view, different views of } \\
\text { consumer trust is shown in a tabular } \\
\text { format. To portray the security, case } \\
\text { study was used. }\end{array}$ & 23 \\
\hline 28 & $\begin{array}{l}\text { Authentication threats like offline } \\
\text { credential-stealing attacks and } \\
\text { online channel-breaking attacks. } \\
\text { Two proposed solutions Short-term } \\
\text { based on hardware token which } \\
\text { generate password and Certificate- } \\
\text { based solution using PKI (RSA). }\end{array}$ & 4 \\
\hline 29 & $\begin{array}{l}\text { Book is categorically divided into } \\
\text { five parts. Focusing on Internet \& } \\
\text { E-Commerce. Security Threats \& } \\
\text { Payment System is one of the most } \\
\text { important topics. Emphasis is given } \\
\text { on Ecommerce, e-learning, issues, } \\
\text { main drivers, benefits \& constraints } \\
\text { of transacting online, security } \\
\text { issues, cryptography, e-wallet etc }\end{array}$ & 24 \\
\hline 30 & $\begin{array}{l}\text { A survey was conducted on } 108 \\
\text { people to see how many people } \\
\text { especially in which country share } \\
\text { the passwords and access internet } \\
\text { on public platforms. Findings were } \\
\text { Married and de facto couples, } \\
\text { remote communities' people and } \\
\text { disable people share the passwords } \\
\text { and majority of the people } \\
\text { specifically the developing } \\
\text { countries citizens' access Internet } \\
\text { publicly. }\end{array}$ & 56 \\
\hline 31 & $\begin{array}{l}\text { The paper discuses how to win } \\
\text { customer trust by understanding the } \\
\text { social \& cultural elements, Gap } \\
\text { between PKI, challenges \& social- } \\
\text { cultural, W3 trust profiling } \\
\text { framework. }\end{array}$ & 65 \\
\hline 32 & $\begin{array}{l}\text { An experiment was conducted on } 50 \\
\text { customers in a controlled } \\
\text { environment to find customer view } \\
\text { about usability, security in two } \\
\text { factor (2-factor) and its potential } \\
\text { conflict in the provision of }\end{array}$ & 21 \\
\hline
\end{tabular}




\begin{tabular}{|c|c|c|}
\hline & $\begin{array}{l}\text { authentication solutions , Push- } \\
\text { Button Token, Card-Activated } \\
\text { Token, Chip and PIN Secured } \\
\text { Token }\end{array}$ & \\
\hline 33 & $\begin{array}{l}\text { Different mode of communication, } \\
\text { Attacks on Electronic Banking } \\
\text { Services, Authentication Methods \& } \\
\text { Mechanisms, Trusted devices and } \\
\text { the objectives of a trusted device }\end{array}$ & 43 \\
\hline 34 & $\begin{array}{l}\text { The paper revolves around the } \\
\text { security of internet. Ventures, } \\
\text { Concerns, issues, Attacks, Software } \\
\text { based solutions (Digital Signature, } \\
\text { Secure Electronic Transaction, } \\
\text { Pretty Good Privacy, and Kerberos), } \\
\text { Hardware based solutions } \\
\text { (Smartcard System, MeChip) }\end{array}$ & 66 \\
\hline 35 & $\begin{array}{l}\text { The paper proposed a concept the } \\
\text { mutual authentication process, } \\
\text { which can make the financial } \\
\text { system highly immune to phishing, } \\
\text { pharming attacks, and to identity } \\
\text { theft \& man-in-the-middle attacks. } \\
\text { Security also is to be implemented } \\
\text { against a compromised client } \\
\text { environment. }\end{array}$ & 11 \\
\hline 36 & $\begin{array}{l}\text { A very small group was studied for } \\
\text { the anti-Phishing knowledge } \\
\text { retention for users. Two groups of } \\
\text { six participant each were judged on } \\
\text { ability to retain the training given } \\
\text { and actual practice. The approach of } \\
\text { sending anti-Phishing tips by email } \\
\text { was compared with a proposed } \\
\text { novel anti- phishing approach. } 3 \\
\text { ratios Correct Decision Rate (CDR), } \\
\text { False Positive Rate (FPR), False } \\
\text { Negative Rate (FNR) were given. }\end{array}$ & 2 \\
\hline 37. & $\begin{array}{l}\text { Theoretical paper discussed the } \\
\text { basics of E-banking, benefits, } \\
\text { issues, challenges and factors } \\
\text { responsible for e-banking } \\
\text { development. It also covers } \\
\text { Authentication methods }\end{array}$ & 34 \\
\hline 38 & $\begin{array}{l}\text { The paper depicts the concept of } \\
\text { phishing and the counter effects of it } \\
\text { to the customer as it reveals the } \\
\text { personal information to the phisher } \\
\text { as they commit frauds. The authors } \\
\text { have given a proposed solution, } \\
\text { which banks can use to protect their } \\
\text { customers which is not very time } \\
\text { consuming and expensive. }\end{array}$ & 5 \\
\hline 39 & $\begin{array}{l}\text { This is an experimental paper used } \\
\text { to detect and predict the phishing } \\
\text { website. The experiment was } \\
\text { conducted on two publicly available } \\
\text { sites "phishtank" from the } \\
\text { phishtank.com and Anti Phishing } \\
\text { Working Group (APWG) which }\end{array}$ & 8 \\
\hline
\end{tabular}

\begin{tabular}{|c|c|c|}
\hline & $\begin{array}{l}\text { maintains a Phishing Archive". To } \\
\text { detect a phishing website the result } \\
\text { shows the two important criteria's } \\
\text { (URL \& Domain Identity) and } \\
\text { (Security \& Encryption). They also } \\
\text { talked about some less significant } \\
\text { criteria's like Page Style, content } \\
\text { and Social Human Factor. }\end{array}$ & \\
\hline 40 & $\begin{array}{l}\text { Focusing on the security of Online } \\
\text { Banking from hackers. Cyber } \\
\text { criminals, } 4 \text { scenarios of security } \\
\text { breach, Various Trojans like the } \\
\text { malicious Zeus and URLzone bank } \\
\text { malware Trojans, how Zeus works, } \\
\text { Cardinal rules of Information } \\
\text { security }\end{array}$ & 40 \\
\hline 41 & $\begin{array}{l}\text { Paper talks about the role of security } \\
\& \text { usability, Benefits \& objectives, } \\
\text { Research methods for usable } \\
\text { security in EU. It also depicts the } \\
\text { communication and relationship } \\
\text { between security and usability in e- } \\
\text { banking. }\end{array}$ & 19 \\
\hline 42 & $\begin{array}{l}\text { Author has cited many live } \\
\text { examples depicting the security } \\
\text { breach because of the use of } \\
\text { passwords. How security can be } \\
\text { breached, how data is being sold to } \\
\text { third party, Has explained it with } \\
\text { varied examples, How to Survive } \\
\text { the Password Apocalypse. The two } \\
\text { factor authentication by Google. }\end{array}$ & 32 \\
\hline 43 & $\begin{array}{l}\text { The study highlights about phishing, } \\
\text { its countermeasures, how the hacker } \\
\text { actually targets the weakest link that } \\
\text { ought to be an innocent customer. } \\
\text { The findings also show the anti- } \\
\text { phishing techniques available today } \\
\text { that are significant for deployments } \\
\text { over the internet can be divided into } \\
8 \text { categories. }\end{array}$ & 55 \\
\hline
\end{tabular}

Security Threats papers were taken into consideration for observing the threats encountered by banks and customers online. There are many security threats like viruses, hackers, crackers, phishing, pharming, etc. Various anti-virus, antiphishing solutions are proposed. The latest technique of OTP (One Time Password), 2D authentication has also been covered nicely

\section{SECURITY SOLUTION}

Security Solution papers are again divided into 2 subsections (Biometrics and online transaction). This set of papers is most relevant and significant to our theme information security in e-banking. We are focusing on securing the information so that the transaction should be completed without any risk of security breach. 


\begin{tabular}{|c|c|c|}
\hline$\#$ & Objective \& Findings & Reference \\
\hline 44 & $\begin{array}{l}\text { The technologies for electronic } \\
\text { payments are now deeply } \\
\text { understood, and various } \\
\text { companies are giving solutions } \\
\text { into the market-place, which is } \\
\text { currently dominated by card based } \\
\text { schemes. The basic concern for } \\
\text { users is to key in their credentials } \\
\text { online, which is now subsiding. }\end{array}$ & 39 \\
\hline 45 & $\begin{array}{l}\text { Various Cryptography techniques } \\
\text { used since its inception till } 2009\end{array}$ & 36 \\
\hline 46 & $\begin{array}{l}\text { Paper deals with various biometric } \\
\text { technologies along with a model } \\
\text { for b-banking based on TAM } \\
\text { model of Davis. Paper focuses on } \\
\text { way of enhancing adoption for } \\
\text { ebanking. }\end{array}$ & 49 \\
\hline 47 & $\begin{array}{l}\text { The use of internet \& further } \\
\text { sharing on images across as } \\
\text { turned very common activity on } \\
\text { internet. The paper is focused on } \\
\text { providing security to images using } \\
\text { encryption technique. }\end{array}$ & 54 \\
\hline 48 & $\begin{array}{l}\text { The paper talks about a firewall } \\
\text { which filters out the attack } \\
\text { packets from the packets sent by } \\
\text { legitimate users before they reach } \\
\text { the victim. By this, they are } \\
\text { combining both Victim Based and } \\
\text { Router Based approaches against } \\
\text { IP spoofing. }\end{array}$ & 35 \\
\hline 49 & $\begin{array}{l}\text { Security Threats with many live } \\
\text { examples, benefits of biometrics, } \\
\text { three factor authentication, } \\
\text { methods offered by e-banking to } \\
\text { provide security }\end{array}$ & 3 \\
\hline 50 & $\begin{array}{l}\text { Author has defined an algorithm } \\
\text { which allows the user to choose } \\
\text { the depth of security according to } \\
\text { which it goes into multiple levels } \\
\text { of encryption. }\end{array}$ & 28 \\
\hline 51 & $\begin{array}{l}\text { Advancement in biometrics \& its } \\
\text { use in security }\end{array}$ & 52 \\
\hline 52 & $\begin{array}{l}\text { This paper depicts multi-level } \\
\text { management and the risk } \\
\text { mitigation approach on a trusted } \\
\text { device to authenticate } \\
\text { transactions. Relevant attack like } \\
\text { (social, physical, software) and } \\
\text { solution properties } \\
\text { (Reasonableness, convenience, } \\
\text { Mobility, Integration, cost } \\
\text { administration), two real world } \\
\text { implementations with regards to } \\
\text { convenience and mobility while } \\
\text { maintaining the highest level of } \\
\text { security }\end{array}$ & 60 \\
\hline
\end{tabular}

\begin{tabular}{|c|c|c|}
\hline 53 & $\begin{array}{l}\text { In this paper, a new algorithm } \\
\text { BREA (Byte - Rotation } \\
\text { Encryption Algorithm is } \\
\text { presented. The BREA algorithm is } \\
\text { a Symmetric Key Block Cipher } \\
\text { Algorithm with a block size and } \\
\text { Key matrix size of } 16 \text { bytes. } \\
\text { Mono alphabetic substitution and } \\
\text { Byte-Rotation technique is used. }\end{array}$ & 51 \\
\hline 54 & $\begin{array}{l}\text { The paper proposed an approach } \\
\text { for securing Android sytem } \\
\text { through Biometric Mechanism. }\end{array}$ & 31 \\
\hline 55 & $\begin{array}{l}\text { The author has proved } \\
\text { mathematically how different } \\
\text { RSA algorithms are vulnerable to } \\
\text { hardware fault attacks. The new } \\
\text { secure way is proposed for RSA } \\
\text { using CRT. }\end{array}$ & 48 \\
\hline 56 & $\begin{array}{l}\text { In this paper the author has } \\
\text { presented varied schemes for } \\
\text { distributing and managing key in } \\
\text { mobile ad hoc. And the } \\
\text { advantages and disadvantages of } \\
\text { each method are being discussed. } \\
\text { It also highlights the varied } \\
\text { approaches being used for } \\
\text { certificate generation, discovering } \\
\text { and authentication of public keys. }\end{array}$ & 37 \\
\hline 57 & $\begin{array}{l}\text { The author has given detailed } \\
\text { description of Information } \\
\text { security using cryptography and } \\
\text { various algorithms. The proposed } \\
\text { algorithm has the better speed } \\
\text { compared with the other } \\
\text { encryption algorithms taken for } \\
\text { research. Nevertheless, the } \\
\text { proposed algorithm has increased } \\
\text { the security by inserting the } \\
\text { symmetric layer. }\end{array}$ & 61 \\
\hline 58 & $\begin{array}{l}\text { The paper proposes an altogether } \\
\text { new way of digital signature } \\
\text { unlike traditional digital signature } \\
\text { which uses the concept of RSA. In } \\
\text { this multiple users are asked to } \\
\text { sign to prevent denial action } \\
\text { which makes it more secure and } \\
\text { strong to authenticate. }\end{array}$ & 6 \\
\hline 59 & $\begin{array}{l}\text { Two factor authentication } \\
\text { biometric key is used. In this } \\
\text { biometric key is generated from } \\
\text { two biometric features. Each } \\
\text { biometric feature will generate its } \\
\text { own key. These two keys are } \\
\text { combined with certain algorithm } \\
\text { to give biometric key. In this } \\
\text { paper, an algorithm is proposed } \\
\text { with which the biometric keys can } \\
\text { be processed to generate } \\
\text { cryptographic key for suitable } \\
\text { encryption procedures. }\end{array}$ & 46 \\
\hline
\end{tabular}




\begin{tabular}{|l|l|l|}
\hline 60 & $\begin{array}{l}\text { Symmetric Cryptography } \\
\text { algorithm is proposed }\end{array}$ & 44 \\
\hline 61 & $\begin{array}{l}\text { The author has tried to design a } \\
\text { new encryption algorithm using } \\
\text { ASCII values. }\end{array}$ & 9 \\
\hline 62 & $\begin{array}{l}\text { The author has showcased an } \\
\text { approach to hide data or secure } \\
\text { data on networks using LSB and } \\
\text { stegnography. An Encoder and }\end{array}$ & $\begin{array}{l}\text { Decoder have been implemented } \\
\text { using MATLAB which takes in an } \\
\text { image as a cover, the secret } \\
\text { message is sent along with it after } \\
\text { encryption using a key. }\end{array}$ \\
\hline 63 & $\begin{array}{l}\text { This paper depicts the } \\
\text { implementation of Google } \\
\text { application cloud on IJCT }\end{array}$ & 10 \\
Foundation. IJCT Foundation has \\
shifted all its data to Google cloud \\
and used RSA algorithm for \\
securing the data.
\end{tabular}

Biometrics is being used very rarely by the banks as it is very expensive and need to use an extra device like iris scanning, finger scan etc. Online transaction for securing the electronic payments is one of the best used and one of the safest methods as it uses the concept of Cryptography.

\section{CONCLUSION}

This review paper, have been taken from various articles, books and papers to identify the factors impacting the growth of online transactions. One of the most essential characteristics of information is to deliver it to the authentic/authorized person. Information ought to be secure. Security plays a significant role especially when it comes to transacting online where money is involved.

As seen in the paper we have reviewed security is a significant part of ebanking, it makes the customer confident to trust their banks. We have read and discussed so many security breaches and threats of which we need to be really cautious from the hackers who hack the password, our accounts and use our data in an illegal way.
These days various researches are going on securing the online transactions. Banks are also focused and are taking special initiatives to secure the data. Let me explain it with an example. ICICI bank website earlier used to have only login and password as security. Later they added the concept of generating OTP (One Time Password) for better security and now they have even upgraded the security by asking the grid of the credit/ debit card. As we can see the banks are putting efforts to build and retain customers' satisfaction and confidence towards the banking security.

Although so much have been done when it comes to security solution like firewall, SSL, HTTPS, many algorithms but still we are striving for the best security measure which can assure the banker and the customer about the security.

\section{REFERENCES}

[1] A. Albadvi and R. Gharaee, "Drivers and Barriers of Ebanking Adoption: Case of Karafarin Bank," in Proc. Third International Conference on Digital Society, 2009.

[2] A. Alnajim, \& M. Munro, "An Evaluation of Users' Anti-Phishing Knowledge Retention," in Proc. International Conference on Information Management and Engineering,2009, pp. 210

[3] A. Fatima, "E-Banking Security Issues - Is There A Solution in Biometrics?," Journal of Internet Banking and Commerce, vol. 16, no.2, August, 2011.

[4] A. Hiltgen, T. Kramp, and T. Weigold, "Secure Internet Banking Authentication," IEEE Security \& Privacy, pp. 24-34, Mar/Apr 2006.

[5] A. K. Devarakonda et al., "Security Solutions to the Phishing: Transactions Based on Security Questions and Image," V.V Das et al. (Eds.): BAIP 2010, CCIS 70, pp. 565-567, 2010 C Springer-Verlag Berlin Heidelberg 2010 Springer-VerlagBerlinHeidelberg, pp. 565-56

[6] A. K. Hussein, "Generating A New Group Digital Signatures," Journal of Emerging Trends in Computing and Information Sciences, VOL. 3, NO. 6, July 2012

[7] A. M. Aladwani, "Online banking: a field study of drivers, development challenges, and expectations", International Journal of Information Management 21, 213-225, 2001.

[8] A. Maher, et al., "Associative Classification Techniques for predicting e-Banking Phishing Websites", in Proc. MCIT 2010 C IEEE, pp. 9-12

[9] A. Mathur, "A Research paper: An ASCII value based data encryption algorithm and its comparison with other symmetric data encryption algorithms," International Journal on Computer Science and Engineering (IJCSE), Vol. 4, No. 09, pp. 1650-1657, Sep 2012.

[10] A. Patial, S. Behal, "RSA Algorithm achievement with Federal information processing Signature for Data protection in Cloud Computing," International Journal of Computers \& Technology, Volume 3. No. 1, pp. 3438, AUG, 2012

[11] A. S. Martino, X. Perramon, "Defending E-Banking Services: Antiphishing Approach," in Proc. The Second International Conference on Emerging Security Information, Systems and Technologies (C) IEEE DOI 
10.1109/SECURWARE.2008.9, pp 978-0-7695-3329$2 / 08$

[12] B. Jaruwachirathanakul and D. Fink, "Internet banking adoption strategies for a developing country: the case of Thailand," Internet Research , Vol. 15 No. 3, pp. 295 311, 2005.

[13] B. F. Zavareh, "E-Service Quality Dimensions and Their Effects on ECustomer Satisfaction in Internet Banking Services," in Proc. The 2012 International Conference on Asia Pacific Business Innovation and Technology Management, Procedia - Social and Behavioral Sciences, pp. 40, 441 - 445, 2012.

[14] B. Nagaria, "Steganographic Approach for Data Hiding using LSB Techniques," International Journal of Advanced Computer Research (ISSN (print): 22497277 ISSN (online): 2277-7970), Volume-2 Number-4, Issue-6, pp. 441-445 December-2012

[15] B. Suh \& I. Han, "Effect of trust on customer acceptance of Internet banking," Electronic Commerce Research and Applications 1, 247-263, 2002.

[16] C. Chambers and U. Turksen, "E-banking and e-fraud: A comparison investigation in Jamaica and the UK," in Proc. Fourth International Conference on Digital Society, 2010.

[17] C. Jayawardhena, P. Foley, "Changes in the banking sector - the case of Internet banking in the UK", Internet Research: Electronic Networking Applications and Policy, Volume 10 . Number 1, pp. 19-30, MCB University Press . ISSN 1066-2243, 2000.

[18] C. Martins, T. Oliveira, A. Popovi, "Understanding the Internet banking adoption: A unified theory of acceptance and use of technology and perceived risk application," International Journal of Information Management, Available: http://dx.doi.org/10.1016/j.ijinfomgt.2013.06.002, 2013.

[19] C. Moeckel, "Human-Computer Interactuon for Security Research: The case of EU E-Banking Systems," in Proc. P. Campos et al. (Eds.): INTERACT 2011, Part IV, LNCS 6949, pp. 406-409, 2011.

[20] C. Sayar, "Internet banking market performance: Turkey versus the UK," International Journal of Bank Marketing, Vol. 25 No. 3, pp. 122-141, 2007.

[21] C. S. Weir, et al., "User perceptions of security, convenience and usability for ebanking authentication tokens," Elsevier Ltd., pp. 47-62, 2009.

[22] C. S. Yiua, K. Grantc \& D. Edgar, "Factors affecting the adoption of Internet Banking in Hong Kongimplications for the banking sector," International Journal of Information Management , 27 , 336-351, 2007.

[23] D. Hutchinson, \& M. Warren, "Security for internet banking: a framework," Logistics Information Management, vol. 16, Number 1, pp. 64-73, 2003.

[24] E. M. Awad, Electronic Commerce: From Vision to Fulfillment, 2nd ed, New Delhi: Pearson Education, Inc. 2007.

[25] H. Jenkins, "Adopting internet banking services in a small island state: assurance of bank service quality", Managing Service Quality, Vol. 17 No. 5, pp. 523-537, 2007.
[26] H. S. Yoon \& L. M. B. Steege, "Development of a quantitative model of the impact of customers' personality and perceptions on Internet banking use," Computers in Human Behavior, pp. 29 , 1133-1141, 2013.

[27] I. Syamsuddin, \& J. Hwang, "The Application of AHP Model to Guide Decision Makers: A Case Study of EBanking Security," in Proc. Fourth International Conference on Computer Sciences and Convergence Information Technology, 2009.

[28] K. Govinda, .E. Sathiyamoorth, "MULTILEVEL CRYPTOGRAPHY TECHNIQUE USING GRACEFUL CODES," Journal of Global Research in Computer Science, Volume 2, No. 7, July 2011

[29] K. Saurabh, S. Singh, "Providing Security in Data Aggregation using RSA Algorithm," International Journal of Computers \& Technology, Volume 3, No. 1, pp. 61-64, AUG, 2012

[30] K. Singh, R. Verma, R. Chehal, "Modified Prime Number Factorization Algorithm (MPFA) For RSA Public Key Encryption," International Journal of Soft Computing and Engineering (IJSCE) ISSN: 2231-2307, Volume-2, Issue-4, pp. 204-206, September 2012

[31] M. Belkhede, V. Gulhane \& P. Bajaj, "Biometric Mechanism for enhanced Security of Online Transaction on Android system: A Design Approach," in Proc. ICACT, 2012, pp. 1193-1197, Feb. 19 22, 2012

[32] M. Honan. (2012) Kill the Password: Why a String of Characters Can't Protect Us Anymore on Wired.com [Online]. Available: Wired.com's Gadget Lab

[33] M. M. Mashhadi, M. Tofighi \& V. Salamat , "Investigating Customers' Decision to Accept Ebanking Services," in Proc. IEEE, 2007.

[34] M. R. Nami, "E-Banking: Issues and Challenges in Proc. 10th ACIS International Conference on Software Engineering, Artificial Intelligences, Networking and Parallel/Distributed Computing, IEEE 2009, pp. 263.

[35] M. Ravi, et al, " A Cryptographic Approach to Defend against IP Spoofing," V.V Das et al. (Eds.): BAIP 2010, CCIS 70 @ Springer-Verlag Berlin Heidelberg, pp 290296, 2010.

[36] N. G. McDonald, "Past, present, and future methods of cryptography and data encryption," Department of Electrical and Computer Engineering, University of Utah, Research Review, 2009

[37] N. Gupta, M. Shrivastava, A. Goel, "Survey paper on different approaches of Threshold Cryptography," International Journal of Advanced Computer Research, (ISSN (print): 2249-7277 ISSN (online): 2277-7970), Volume-2 Number-3 Issue-5 September-2012 Volume2 Number-3 Issue-5 September-2012

[38] N. O. Ndubisi and Q. Sinti, "Consumer attitudes, system's characteristics and internet banking adoption in Malaysia”, Management Research News, Vol. 29 No. 1/2, pp. 16-27, 2006.

[39] P A Putland, C Ward, A Jackson and C Trollope, "Electronic payment systems," BT Technol J, Vol 17, No 3, pp. 67-71, July 1999. 
[40] P. J. Marshall, "Online Banking: Information Security vs. Hackers Research Paper," International Journal of Scientific \& Engineering Research, Volume 1, Issue 1, October-2010

[41] P. Gerrard, J. B. Cunningham, "The diffusion of internet banking among Singapore consumers," International journal of Bank Marketing, 21/1 ,16-28, 2003.

[42] P. Gerrard, J. B. Cunningham and J.F. Devlin, "Why consumers are not using internet banking: a qualitative study," Journal of Services Marketing, Emerald Group Publishing Limited[ISSN 0887-6045], 2006.

[43] P. Hanaeek et al., "E-Banking Security -A Comparative Study," in Proc. ICCST (C) IEEE 2008, pp. 326.

[44] P. Kuppuswamy, \& S.Q. Y Al-Khalidi, "Implementation of security through simple symmetric key algorithm based on modulo 37," International Journal of Computers \& Technology, Volume 3, No. 2, OCT, 2012

[45] P. Malhotra \& B. Singh, "Determinants of Internet banking adoption by banks in India," Internet Research, Vol. 17 No. 3, pp. 323-339, 2007.

[46] P. M. Kannan, A. Asthana, "Secured Encryption Algorithm for Two Factor Biometric Keys," International Journal of Latest Research in Science, Vol.1,Issue 2 :Page No.102-105 ,July .August (2012)

[47] P. O. Magutu et.al, "E-Commerce Products and Services in the Banking Industry: The Adoption and Usage in Commercial Banks in Kenya," Journal of Electronic Banking Systems, Vol. 2011 , Article ID 678961, 19 pages, 2011.

[48] R.R. Chaudhary, D. Kelkar, V.Arya, “ Secure Three Prime RSA from Hardware Fault Attack," International Journal of Advanced Computer Research, (ISSN (print): 2249-7277 ISSN (online): 2277-7970), Volume 1, Number 2, December 2011

[49] R. Tassabehji, \& M. A Kamala, "Improving E-Banking Security with Biometrics: Modelling user attitudes and acceptance," IEEE 978-1-4244-6273-5/09, 2009

[50] S. Akinci, S. Aksoy and E. Atilgan, "Adoption of Internet banking among sophisticated consumer segments in an advanced developing country", The International Journal of Bank Marketing, Vol. 22 No. 3, pp. 212-232, 2004.

[51] S. Bhati, A. Bhati, S. K. Sharma, "A New Approach towards Encryption Schemes: Byte - Rotation Encryption Algorithm," in Proc. of the World Congress on Engineering and Computer Science 2012, Vol. II, WCECS 2012, October 24-26, 2012, San Francisco, USA

[52] S. Jain, S. Gupta, \& R. K Thenua, "A review on Advancements in Biometrics," International Journal of Electronics and Computer Science Engineering, ISSN 2277-1956/V1N3, vol. 1, Number 3, pp. 853-859, 2011.

[53] S. Kurnia, F. Peng and Y. R. Liu, "Understanding the Adoption of Electronic Banking in China," in Proc. of the 43rd Hawaii International Conference on System Sciences, 2010.

[54] S. P. Indrakanti, P. S. Avadhani, "Permutation based Image Encryption Technique," International Journal of
Computer Applications (0975 - 8887), Volume 28No.8, pp. 45-47, August 2011

[55] S. Purkait, "Phishing counter measures and their effectiveness - literature review," Information Management \& Computer Security, Vol. 20 Issue: 5 pp. $382-420$

[56] S. Singh, et al., "Security Design Based on Social and Cultural Practice: Sharing of Passwords," SpringerVerlag Berlin Heidelberg, pp. 476-485, 2007.

[57] S. Singh, "The social dimensions of the security of internet banking," Journal of theoretical and applied social science \& Research, Vol 1, pp 72-78, 2006.

[58] S. Y. Wang et al., "Determinants of user acceptance of Internet banking: an empirical study," International Journal of Service Industry Management, Vol. 14 No. 5, pp. 501-51, 2003.

[59] T. Laukkanen, S. Sinkkonen, and P. Laukkanen, "Communication strategies to overcome functional and psychological resistance to Internet banking,", International Journal of Information Management , 29 , 111-118, 2009.

[60] T. Weigold, \& A. Hiltgen, "Secure Confirmation of Sensitive Transaction Data in Modern Internet Banking Services," in Proc. WorldCIS 2011 Conference, 2011.

[61] V. Gupta et. al., "Advance cryptography algorithm for improving data security," International Journal of Advanced Research in Computer Science and Software Engineering, ( ISSN: 2277 128X), Vol. 2, issue 1, Jan 2012.

[62] V. Shukla, A. Choubey, "A Comparative analysis of the attacks on public key RSA cryptosystem," INTERNATIONAL JOURNAL OF INNOVATIVE TECHNOLOGY \& CREATIVE ENGINEERING (ISSN:2045-8711), VOL.2,NO.2, pp. 6-11, FEB 2012

[63] W. Nasri, \& L. Charfeddine, "Factors affecting the adoption of Internet banking in Tunisia: An integration theory of acceptance model and theory of planned behavior," Journal of High Technology Management Research 23, 1-14, 2012.

[64] Wan W. N. Wendy, 'Customers' adoption of banking channels in Hong Kong," International Journal of Bank Marketing Vol. 23 No. 3, pp. 255-272, 2005.

[65] Y. Yang, E. Lewis, \& L. Brown, "Cultural and Social Aspects of Security and Privacy -The Critical Elements of Trusted Online Service," in Proc. N. Aykin (Ed.): Usability and Internationalization, Part II, HCII 2007, LNCS 4560, pp. 546-553, 2007 (C) Springer-Verlag Berlin Heidelberg

[66] Y. Yang, "The Security of Electronic Banking," IEEE, pp 763-766 